\title{
Measuring the Effectiveness of the EU Civil Justice Framework: Theoretical and Methodological Challenges
}

\author{
Mihail Danov and Paul Beaumont**
}

\begin{abstract}
A number of harmonised private international law instruments appear to be the foundation of the whole EU civil justice framework, which primarily aims to provide effective remedies for litigants in crossborder cases. Given the level of diversity across the EU, a major feature of the EU legal landscape is the triangular relationship between the allocation of jurisdiction and identification of applicable law, on the one hand, and the available remedy, on the other hand. It appears that, when it comes to the administration of justice in a cross-border context within the EU, this triangular relationship encompasses the ability of the Member States' courts to deal with cross-border disputes which may be important for the forum selection process. An EU model of administration of justice, which allows litigants to choose where to litigate, may result in some jurisdictions being promoted as dominant. This can only happen, of course, because the EU has already created free movement of judgments in large areas of commercial and family law. Once a judgment has been secured in any one EU Member State it should be enforceable in all others with little or no hindrance. However, litigants may have to consider where a judgment is to be actually enforced given that the rules on actual enforcement are not harmonised in the EU (this may be particularly significant in relation to family law disputes). The dominant jurisdictions could be attracting more cross-border cases, and thus some jurisdictions may become a venue of choice for the high value cross-border disputes. It is important to assess, on the basis of relevant empirical data, how the current EU Civil Justice framework is shaping the litigants' strategies and whether the objectives of the EU PIL legislative instruments are effectively pursued in a cross-border context. An empirical study is underway in several Member States, with different legal traditions/heritages.
\end{abstract}

\footnotetext{
${ }^{* *}$ Respectively, Associate Professor in Law, University of Leeds, and Professor of European Union and Private International Law and Director of the Centre for Private International Law of the University of Aberdeen. This paper is written within the framework of research project JUST/2013/JCIV/AG/4635 on 'Cross-Border Litigation in Europe: Private International Law Legislative Framework, National Courts and the Court of Justice of the European Union'. The project, which includes also Professor Stefania Bariatti (University of Milan, Italy), Professor Jan von Hein (University of Freiburg, Germany), Professor Carmen Otero (Universidad Complutense de Madrid, Spain), Professor Thalia Kruger (University of Antwerp, Belgium) and Dr Agnieszka Frąckowiak-Adamska (University of Wroclaw, Poland), attracted over €730,000.00 in financial support from the EU Commission Civil Justice Programme. The usual disclaimers, including the disclaimer excluding the Commission's responsibility, apply. This article will be published in the (2015-16) XVII Yearbook of Private International Law.
} 


\section{INTRODUCTION}

It is well established that there is free movement of workers, goods, capital and services in a growing and diverse European Union which consists of 28 Member States, sharing different legal heritages. The diverse nature of the legal systems across the European Union indicates that private law in Europe is difficult to harmonise. The main reason being that '[o]nly in legal fields where considerable harmonization had taken place already would it be productive to implement the unification or uniformity of positive law'. ${ }^{1}$ Given the character of the Union, a number of private international law (PIL) instruments were adopted on the basis of Article 81 of the Treaty on the Functioning of the European Union. ${ }^{2}$

The role of private international law, which does not have an ambition to harmonise national substantive laws and may only harmonise national procedural laws in a very limited way to achieve certain goals of private international law harmonisation including administrative and judicial cooperation, is very important in the EU. The EU PIL Regulations are legislative tools used by the EU legislature to preserve the inherent characteristics of the diverse legal systems within the EU. ${ }^{3}$ Sets of EU private international law mechanisms are adopted to facilitate all cross-border litigation arising out of private relationships. These sets of rules have put in place administrative and judicial cooperation mechanisms which are intended to facilitate the administration of justice in cross-border family cases and to a much lesser extent in civil and commercial law disputes arising in an intra-EU context. The harmonised private international law instruments are the foundation of the whole EU civil justice framework, which primarily aims to provide effective remedies ${ }^{4}$ to the parties in cross-border civil and commercial law cases across the EU. ${ }^{5}$

\footnotetext{
${ }^{1}$ D.J. Gerber, 'Sculpting the agenda of comparative law: Ernst Rabel and the Facade of Language', in A. Riles (ed.), Rethinking the Masters of Comparative Law (Hart Publishing, 2001), p. 190, 216.

${ }^{2}$ See more: P. Beaumont and M. Danov, 'The EU Civil Justice Framework and Private Law: “Integration through [Private International] Law”' (2015) 22 Maastricht Journal of European and Comparative Law 706731.

${ }^{3}$ H. Muir Watt, 'Integration and diversity: The conflict of laws as a regulatory tool', in F. Cafaggi (ed.), The Institutional Framework of European Private Law (OUP, 2006), p. 107; L. Tichy, 'A new role for private international law and procedural law in European Integration? A critical comment', in R. Brownsword et al. (eds.), The Foundations of European Private Law (Hart Publishing, 2011), p. 393-412. See also, European Council, The Stockholm Programme - An open and secure Europe serving and protecting the citizens, [2010] OJ C 115/1, p. 15.

${ }^{4}$ P. Beaumont, 'Interplay of Private International Law and European Community Law' in C. Kilpatrick, T. Novitz and P. Skidmore (eds), The Future of Remedies in Europe (Hart Publishing, Oxford 2000) 197. See also: C. Harlow, 'A Common European Law of Remedies’ in C. Kilpatrick, T. Novitz and P. Skidmore (eds), The Future of Remedies in Europe (Hart Publishing, Oxford 2000) 69.

${ }^{5}$ Article 47(1) of the EU Charter of Fundamental Rights of the European Union; Communication from the Commission, The EU Justice Agenda for 2020 - Strengthening Trust, Mobility and Growth within the Union, COM(2014) 144 final, para 4.1(ii); Recital 38 of Brussels I Recast Regulation.
} 
At present, there is a growing number of harmonised EU private international law mechanisms which form part of the Member States' legal orders. In particular, EU private international law rules are relied upon by the EU policy-makers to allocate jurisdiction between the Member States' courts and identify the applicable laws to the merits of civil and commercial law disputes (including family law disputes) with an international element. Council Regulation 1215/2012 ('Brussels I recast') is to be used by national courts when assuming jurisdiction in civil and commercial matters as well as when another Member State's court judgment is sought to be registered and enforced. Council Regulation 593/2008 ('Rome I') and Council Regulation 864/2007 ('Rome II') are intended to designate the national law which should apply to the merits of cross-border disputes of a contractual and/or non-contractual nature.

Council Regulation 2201/2003 ('Brussels IIa') and Council Regulation 4/2009 ('Maintenance Regulation') are relevant for a Member State court, assuming jurisdiction in certain family law disputes, as well as for the other Member States' courts where the rendered judgment in such disputes is sought to be registered and enforced. However, the EU legal landscape is somewhat more complex and diverse with regard to the law applicable in matrimonial and maintenance matters. Council Regulation 1259/2010 implementing enhanced cooperation in the area of the law applicable to divorce and legal separation ('Rome III') and the Hague Protocol on the law applicable to maintenance obligations apply in some Member States, but not in others. ${ }^{6}$

Moreover, different sets of private international law instruments do achieve a level of harmonisation with regard to such procedural aspects as, for example, avoidance of parallel

\footnotetext{
${ }^{6}$ The Brussels I recast [2012] OJ L351/1 and the Maintenance Regulation [2009] OJ L7/1 apply in all Member States (in Denmark - by an international agreement between the EC and Denmark of 19 October 2005 [2005] OJ L299/62 and subsequent notifications by Denmark on Maintenance [2009] OJ L149/80 and the Brussels I Recast [2014] OJ L240/1; in the UK the Maintenance Regulation was opted in to by the UK after its adoption see [2009] OJ L149/73); Brussels IIa [2003] OJ L338/1, Rome I [2008] L177/6 and Rome II [2007] L199/40 apply in all Member States, except Denmark; Rome III is a product of enhanced cooperation [2010] OJ L343/10 and only applies in Belgium, Bulgaria, Germany, Greece (see [2014] OJ L23/41), Spain, France, Italy, Latvia, Lithuania (see [2012] OJ L323/18, Luxembourg, Hungary, Malta, Austria, Portugal, Romania and Slovenia. The Hague Maintenance Protocol applies in all Member States except Denmark and the UK, see Council Decision 941/2009 on the conclusion by the EC of the Hague Protocol of 23 November 2007 on the law applicable to maintenance obligations [2009] OJ L331/17.
} 
proceedings, ${ }^{7}$ transfer of parental responsibility proceedings within the EU, ${ }^{8}$ service of documents, ${ }^{9}$ taking of evidence across borders. ${ }^{10}$

The adoption of so many private international instruments indicate that, in order to ascertain whether there are effective remedies for litigants in cross-border cases, one may consider the implications of the EU private international law mechanisms on the administration of justice across the EU. In theory, some analogies may be drawn with the developments in England and Wales. In a domestic context, Sir Jack Jacob ${ }^{11}$ has used the concept of "civil justice", in order to "describe the entire system of the administration of justice in civil matters.” ${ }^{12}$ In a broader European context, the Brussels I regime inter alia was set "to facilitate the sound administration of justice" ${ }^{13}$ in the EU. In England, Dame Hazel Genn ${ }^{14}$ has submitted that "[t]he civil justice system is partly about substantive rights, ${ }^{15}$ but perhaps more importantly it is about the provision that society makes for citizens and business to bring civil suits - the right of action and the machinery to make good that right.” ${ }^{16}$ In Europe, the EU Justice Agenda for 2020 has expressly provided that "[t]here are no rights without effective remedies". ${ }^{17}$ Hence, in the EU context, it could be argued that the institutional framework in the EU would be central to providing private parties with effective remedies in cases with an international element.

The theoretical and practical issues are important because remedies in a cross-border context may be necessary not only for businesses, but also for consumers as well as for particularly vulnerable people (eg maintenance creditors and children who have been abducted) which poses important questions about access to justice and remedies in the EU. Therefore, it is important to consider the effectiveness of the current EU civil justice system and in particular the effectiveness of the harmonised private international law instruments,

\footnotetext{
${ }^{7}$ e.g. Articles 29 - 32 of the Brussels I Recast Regulation; Article 19 of the Brussels IIa Regulation; Articles 12 and 13 of the Maintenance Regulation.

${ }^{8}$ Article 15 of the Brussels IIa Regulation.

${ }^{9}$ Council Regulation (EC) No 1393/2007 of 13 November 2007 on the service in the Member States of judicial and extrajudicial documents in civil or commercial matters (service of documents), and repealing Council Regulation (EC) No 1348/2000 [2007] OJ L324/79.

${ }^{10}$ Council Regulation (EC) No 1206/2001 of 28 May 2001 on cooperation between the courts of the Member States in the taking of evidence in civil or commercial matters [2001] OJ L174/1.

11 J. I. H. Jacob, The Fabric of English Civil Justice (Stevens \& Sons, London 1987).

12 Ibid p 2.

${ }^{13}$ Recital 16 of Regulation (EU) 1215/2012 ('Brussels I recast').

${ }^{14}$ H. Genn, Judging Civil Justice (CUP, Cambridge 2010).

${ }^{15}$ See the discussion by J. A. Jolowicz in 'On the nature and purpose of civil procedure law', Chapter 3 in J. A. Jolowicz, On Civil Procedure (Cambridge University Press, 2005) cited in H. Genn, Judging Civil Justice (CUP, Cambridge 2010) p 11.

${ }^{16}$ H. Genn, Judging Civil Justice (CUP, Cambridge 2010) p 11.

${ }^{17}$ Communication from the Commission, The EU Justice Agenda for 2020 - Strengthening Trust, Mobility and Growth within the Union, $\operatorname{COM}(2014) 144$ final, para 4.1(ii).
} 
which are being drafted and applied in a diverse Union. A major concern in the EU is that many of the legislative instruments may be a result of a compromise achieved at EU level. It has been submitted by Kerber $^{18}$ that:

"collective decision-making implies large costs such as knowledge, rent-seeking problems, inefficiencies, or inflexibility, it might be that considerable costs through market failure must also be accepted before it is advisable to turn to centralization or mobility barriers." ${ }^{19}$

One might question the effectiveness of legislative instruments which may be affected by a level of political pressure from Member States as well as from the EU policy-makers. Beaumont and McEleavy have made the following observation, which captures well the issues which must be carefully considered:

"[PIL m]easures are adopted in pursuit of short-term goals, in accordance with what is politically expedient or achievable at a particular moment in time. This in turn has led to a disjointed, piecemeal approach to law making, in which the replacement or constant revision of instruments has become an accepted norm. But of course this is a practice with significant costs, both for Member States, which are continually engaged in legislative reform, and for individuals and their legal advisers who must grapple with constantly changing legal frameworks." 20

The ineffectiveness of the legislative process may result in the adoption of private international law instruments which generate a level of uncertainty/ambiguity for crossborder litigants. The level of uncertainty may be significantly amplified, if the current EU institutional framework does not ensure that the adopted private international law instruments are consistently and swiftly applied by 28 Member States' courts. The issues would be significant because there is a level of complexity that characterises the cross-border cases which, by their very nature, would have a connection with more than one legal system. An ineffective EU civil justice system, which is not adjusted (or is not capable of swift adjustment) to effectively cope with abusive litigation tactics, would inflate the litigation costs even further. In other words, an ineffective EU civil justice system would inevitably have an impact on litigants' strategies and the relevant settlement dynamics, making it even harder for parties (or for certain parties which have no access to finance) to obtain effective remedies in cross-border cases.

There is a need for considering answers to the following research questions: (1) Do national courts deal appropriately with harmonised private international law instruments? (2) Does the CJEU deal appropriately with private international law issues? (3) Is the institutional architecture in the EU suited to providing an “effective remedy” for cross-border

\footnotetext{
${ }^{18}$ W. Kerber, 'Interjurisdictional competition within the European Union’ (1999-2000) 23 Fordham International Law Journal S217

${ }^{19}$ Ibid S229.

${ }^{20}$ P. Beaumont and P. McEleavy, Anton's Private International Law ( $3^{\text {rd }}$ edn, SULI 2011) p 71.
} 
litigants whose rights have been violated ${ }^{21}$ ? (4) Is there a need for reform? If so, what should be the direction of any potential reform?

It has been noted by the EU policy-makers that: 'There has to be an evaluation of the effectiveness of the legal instruments adopted at Union level. Evaluation is also necessary to determine any obstacles to the proper functioning of the European judicial area'. ${ }^{22}$ That said, measuring the effectiveness of the current EU Civil Justice framework - with a view to providing answers to the above research questions - presupposes for the authors to evaluate how effectively and consistently the current EU PIL framework is functioning in different EU Member States. The criterion of effectiveness will be used when doing the assessment for the purposes of this project. It is well established that the effectiveness "refers to the relationship between the anticipated effects of a policy and those that actually emerge in social reality.” 23 The research findings should help to indicate how the EU civil justice framework should evolve, so that 'a Europe of law and justice' ${ }^{24}$ can be created.

To this end, the authors are undertaking an evaluation research project, ${ }^{25}$ measuring whether the objectives, which are set in the recitals of the harmonised PIL instruments, are effectively pursued in the EU. It should be noted that the researchers do not aim to compare the situation before and after the entry into force of the PIL instruments, but rather analyse in depth how the EU PIL framework is functioning in a sample of Member States ${ }^{26}$ while attempting to obtain less comprehensive reports on how the framework is functioning in most if not all the other Member States. In this context, it should be considered how the current private international law regime, which is being applied by different Member States' courts across the EU, is shaping the private litigants' strategies in the EU.

The aim of this paper is to outline the central theoretical and methodological aspects which need to be carefully considered when measuring the effectiveness of the current EU PIL framework.

\footnotetext{
${ }^{21}$ Compare: Article 47(1) of the Charter for Fundamental Rights.

${ }^{22}$ European Council, The Stockholm Programme - An open and secure Europe serving and protecting the citizens, [2010] OJ C 115/1, p. 6.

${ }^{23}$ See more: F. Varone, B. Rihoux and A. Marx, 'A New Method for Policy Evaluation? Longstanding Challenges and the Possibilities of Qualitative Comparative Analysis (QCA)’ in B. Rihoux and H. Grimm, Innovative Comparative Methods for Policy Analysis (Springer, 2006) 213, 215.

${ }^{24}$ European Council, The Stockholm Programme - An open and secure Europe serving and protecting the citizens, [2010] OJ C 115/1

${ }^{25}$ See more: F. Varone, B. Rihoux and A. Marx, ‘A New Method for Policy Evaluation? Longstanding Challenges and the Possibilities of Qualitative Comparative Analysis (QCA)’ in B. Rihoux and H. Grimm, Innovative Comparative Methods for Policy Analysis (Springer, 2006) 213, 215.

${ }^{26}$ M. Adams and J. Bomhoff, 'Comparing Law; Practice and Theory’ in M. Adams and J. Bomhoff (eds), Practice and Theory in Comparative Law (CUP, Cambridge 2012) 1, 6-9.
} 


\section{PIL THEORY: DEFINING JUSTICE IN CROSS-BORDER PRIVATE DISPUTES IN}

\section{THE EU}

The theoretical question that the authors aim to address is about the concept of justice in cross-border cases arising in an intra-EU context. The PIL scholars have extensively considered the concept of "conflicts justice", ${ }^{27}$ "the problem of justice presented by multistate cases" ${ }^{28}$ and "the principles of justice at the choice of law level". 29 "Conflicts justice” has been defined as "a peculiar brand of justice that is readily satisfied by the application of the law most closely connected with a particular transaction.” 30

The importance of identifying the law which is most closely related to a particular legal relationship has been reflected in Rome I, Rome II, Rome III and the Hague Maintenance Protocol. The main objective, which the EU policy-makers appear to pursue, is to enhance the level of legal certainty ${ }^{31}$ and predictability ${ }^{32}$ for litigants in cross-border cases. In civil and commercial cases, this has been achieved by ensuring that the same national law applies irrespective of where the parties litigate their cross-border disputes. ${ }^{33}$ For example, it is well established that "[t]he princip[le] of closest connection remains the basic connecting factor underpinning all of [the] eight categories of Article 4(1)” ${ }^{34}$ of Rome I which applies in cases where the parties have not chosen the law which should apply to their contract. Similarly, by way of another example, it should be noted that "[t]he draftsmen of the Rome II Regulation have assumed that damage always takes place in a country.” ${ }^{35}$ However, the theories

\footnotetext{
${ }^{27}$ G. Kegel, Internationales Privatrecht (6 $6^{\text {th }}$ ed. 1987) 186-187, 193 cited in F. K. Juenger, Choice of Law and Multistate Justice (Martinus Hijhoff Publishers, Dordrecht 1993) p. 69.

${ }^{28}$ A. T. von Mehren, 'Conflict of Laws in a Federal System: Some Perspectives' (1969) 18 International and Comparative Law Quarterly 681.

${ }^{29}$ A. J. E. Jaffey, Topics in Choice of Law (BIICL, London 1996) p 14.

${ }^{30}$ F. K. Juenger, Choice of Law and Multistate Justice (Martinus Hijhoff Publishers, Dordrecht 1993) p. 69. Conflicts justice underlies the notion of “justice” referred to in Recital 14 of Rome II.

${ }^{31}$ Recital 16 of Regulation (EC) No 593/2008 of the European Parliament and of the Council of 17 June 2008 on the law applicable to contractual obligations (Rome I Regulation), [2008] OJ L177/6; Recital 6 of Regulation (EC) No 864/2007 of the European Parliament and of the Council of 11 July 2007 on the law applicable to noncontractual obligations (Rome II Regulation), [2007] OJ L199/40; Recital 3 of the Council Decision on the Conclusion by the EC of the Hague Maintenance Protocol.

${ }^{32}$ Recitals 9 and 21 of Council Regulation (EU) No 1259/2010 of 20 December 2010 implementing enhanced cooperation in the area of the law applicable to divorce and legal separation (Rome III Regulation) and Recital 3 of the Council Decision on the Conclusion by the EC of the Hague Maintenance Protocol.

${ }^{33}$ Recital 6 of Rome I Regulation; Recital 6 of Rome II Regulation.

${ }^{34}$ M. McParland, The Rome I Regulation on the Law Applicable to Contractual Obligations (OUP, Oxford 2015) p 361. See also: R. Plender and M. Wilderspin, The European Private International Law of Obligations (Sweet \& Maxwell, London 2015) pp 176-178 and 185.

${ }^{35}$ R. Plender and M. Wilderspin, The European Private International Law of Obligations (Sweet \& Maxwell, London 2015) p 522.
} 
"assign[ing] each legal relationship to one particular state” ${ }^{6}$ may not easily work in practice. ${ }^{37}$ Although the EU legislation has expressly provided, under Rome II, for a set of special rules ${ }^{38}$ to be applied in cases where "the harmful event and damage typically occur in different countries," 39 there is a risk that the various EU Member States' courts might somewhat inconsistently apply the EU PIL rules. Von Mehren has stated that "[s]peaking realistically, such rules and principles can only be achieved by entrusting their interpretation and application to international authorities.” 40

In addition, there may be difficult issues in cases where one EU Member State's court is willing to apply the law of another Member State. ${ }^{41}$ Fentiman has submitted that " $[\ldots]$ there remains a nagging doubt that no legal rule can be uniformly applied in another court because a judge applying foreign law will always lack the necessary 'internal attitude.’”42 The practical hurdles in this context appeared to shape the litigants' strategies in Sheraleen Boyd Munro $v$ Ian Munro. ${ }^{43}$ In this case, Mr Justice Bennett made the following observations:

" $5[\ldots]$ if proceedings are begun in Spain, it is common ground [...] that the Spanish court will
apply English law to determine the real issue in this case, which is what financial provision, if
any, is to be made by the husband for the wife. The Spanish judge will thus, most likely, need
the assistance of expert evidence on behalf of the parties as to what financial provision an
English judge would be likely to make, applying English law. The parties would thus not have
the most suitable body to decide upon financial provision under English law, namely an
English court. This of course is not a criticism of the Spanish court, merely, I would have
thought, a statement of the obvious.
$6[\ldots]$ I must say that I have to suspect that [...] the husband's attitude may be driven by
tactical considerations, namely either to wear down the wife and/or in an expectation that a
Spanish judge would award the wife significantly less financial provision than an English
judge.." 44

Moreover, a particular theoretical challenge in the European Union context with the concept of "conflicts justice”, as defined above, is that it ignores the concept of "procedural

\footnotetext{
${ }^{36}$ E. Scole, P. Hay, P. Borchers and S. Symeonides, Conflict of Laws (St. Paul, West, $4^{\text {th }}$ ed, 2004) p 17, discussing Savigny's System des heutigen Romischen Rechts (1849) p 108.

${ }^{37}$ A. T. von Mehren, Adjudicatory Authority in Private International Law: A Comparative Study (Martinus Nijhoff Publishers, Leiden 2007) p. 5

${ }^{38}$ E,g. Article 6(3)(a) and (b) of Rome II.

${ }^{39}$ R. Plender and M. Wilderspin, The European Private International Law of Obligations (Sweet \& Maxwell, London 2015) p 522.

${ }^{40}$ A. T. von Mehren, Adjudicatory Authority in Private International Law: A Comparative Study (Martinus Nijhoff Publishers, Leiden 2007) p. 5.

${ }^{41}$ S. Geeroms, Foreign Law in Civil Litigation: A Comparative and Functional Analysis (OUP, Oxford 2003).

${ }^{42}$ R. Fentiman, 'Methods and approaches - Choice of Law in Europe: Uniformity and Integration' (2007-2008) 82 Tul L Rev 2021, 2035-6. See also: H. L. A. Hart, The Concept of Law 89 (3 ${ }^{\text {rd }}$ ed, OUP Oxford 2012) p 89; R. Dworkin, 'No Right Answer?' in P. M. S. Hacker and J. Raz (eds), Law Morality and Society: Essays in Honour of H. L. A. Hart (Clarendon Press, Oxford 1977) 58.

${ }^{43}$ Sheraleen Boyd Munro v Ian Munro [2007] EWHC 3315 (Fam).

${ }^{44}$ Ibid [5-6].
} 
conflicts justice» ${ }^{45}$ which, in the light of Brussels Ia and IIa, is central to the administration of justice in the EU. The success of the Brussels regime in the EU strongly suggests that a different definition of justice in the EU may be needed. The deduction could be strengthened by putting forward that the level of harmonisation, which has already been achieved for some procedural aspects relevant to cross-border private disputes in the EU, is a truly unique feature which characterises the EU civil justice system. The point is captured well by Garnett $^{46}$ who noted that:

"In the area of procedural law, given the strong connections between procedure and the social, political, and economic mores of a country and the consequent greater differences in procedural laws between countries, ${ }^{47}$ harmonization has proved difficult with only a few, limited regional examples such as the EU Council Regulation on Jurisdiction and Judgments" ${ }^{48}$

The Brussels I Recast Regulation (which is the most recently adopted PIL instrument) went further, aiming to guarantee the litigants' right to an effective remedy and to a fair trial in cross-border cases. ${ }^{49}$ These developments suggest that, in order to define justice for the purposes of the EU civil justice framework, an analysis of Member State courts' practice under the Brussels Ia, Brussels IIa, Rome I and Rome II and Maintenance Regulations is needed. This analysis should consider, in a European Union context, what the relationship is between allocation of jurisdiction before an appropriate Member State court and identification of applicable law, on the one hand, and substantive outcomes (including some aspects of the recognition and enforcement of foreign judgments which may need to be considered) in a cross-border dispute, on the other hand. The need to do such analyses could be strengthened by way of making analogy with the domestic civil and commercial disputes, where it is well established that there is a link between the procedure and the substantive outcome. ${ }^{50}$ Genn has submitted that "[i]f substantive justice lies in the correct application of legal principles to a factual situation, then procedures that increase the likelihood of a correct decision being reached are vital.” ${ }^{51}$ In other words, the concept of justice in an EU context does indicate that the availability of an effective remedy in cross-border cases may depend on the place where the proceedings are initiated as well as on the applicable substantive and

\footnotetext{
${ }^{45}$ A. T. von Mehren, Adjudicatory Authority in Private International Law: A Comparative Study (Martinus Nijhoff Publishers, Leiden 2007) p. 29.

${ }^{46}$ R. Garnett, Substance and Procedure in Private International Law (OUP, Oxford 2012).

47 A. Lowenfeld, 'Introduction: The Elements of Procedure: Are they separately portable?' (1997) 45 AJCL 649, 652; C. Hodges, ‘Europeanisation of Civil Justice: Trends and Issues’ (2007) 26 Civil Justice Quarterly 96, 109.

${ }^{48}$ R. Garnett, Substance and Procedure in Private International Law (OUP, Oxford 2012) 67-68.

${ }^{49}$ Recital 38 of Brussels I Recast Regulation.

${ }^{50}$ H. Genn, Judging Civil Justice (CUP, Cambridge 2010) p 14.

${ }^{51}$ Ibid.
} 
procedural laws. The fact that, under the EU civil justice framework, a private party might need to carefully consider the relationship between the relevant procedural rules and the available remedy was recently noted in Wall v Mutuelle de Poitiers Assurances ${ }^{52}$ where $\mathrm{Mr}$ Justice Tugendhat held that:

\begin{abstract}
"16 [...] some practices in the common law states are unknown in most civil law states. Rules of evidence also differ widely. Practices specific to common law states include an obligation on litigants to disclose documents which adversely affect their own case or support another party's case (CPR r 31.6(b)), the preparation and exchange of witness statements for use at trial (CPR $r$ 32.4), and the cross-examination of witnesses, both witnesses of fact and expert witnesses.

17 The adversarial procedures in common law states are designed to assist the court to arrive at the truth. But they require more work to be done by litigants and their lawyers (often with correspondingly less work to be done by the judge) than is required under most civil law inquisitorial systems. The result is that the direct costs of litigation which have to be borne by the parties are much higher in the common law states. This is so, even when the comparison is between a civil law and a common law state where rates of remuneration charged by lawyers are at comparable levels. On the other hand, in the common law states fewer judges are required, and fewer cases are actually tried, instead of being settled. These facts may help to keep down the cost to the common law states of providing for the administration of justice. Having regard to the differences of procedure, it is not surprising that outcomes are different, even in those cases where there is no significant difference between the provisions of the substantive laws of the states in question.” 53
\end{abstract}

In theory, there is a strong case that the EU legislative developments do indicate that the EU concept of justice in cross-border private cases would need to be broadened, in order to cover certain procedural aspects which are dealt with in the EU PIL instruments. Indeed, the triangular relationship between the relevant set of procedural laws, the governing substantive laws and the available remedy may well be among the primary considerations which are affecting the parties' litigation tactics and settlement dynamics in cross-border cases. In other words, the need for the parties to obtain an effective remedy in such cases may be determinative for the parties' decision where to sue as well as for parties' strategies regarding governing law. There are a number of examples which illustrate that this triangular relationship has a significant impact on the litigants' strategies and any settlement dynamics in the EU.

First, a research project on Cross-Border EU Competition Law Actions ${ }^{54}$ demonstrates that, due to the level of variation in the area of private antitrust enforcement in Europe, there could be legitimate advantages (mostly procedural law advantages, but also substantive law advantages) for sophisticated claimants who may be in a position to choose whether to establish jurisdiction in one jurisdiction rather than another. Although the EU legislature has

\footnotetext{
52 [2013] EWHC 53 (QB).

53 Ibid [16-17].

${ }^{54}$ M. Danov, F. Becker and P. Beaumont (eds), Cross-Border EU Competition Law Actions (Hart Publishing, Oxford 2013).
} 
recently adopted a Directive ${ }^{55}$ in the area, there is a strong case that private antitrust claimants, who are prepared to pay the high litigation costs, may well use the relevant PIL framework in place to their advantage, with a view to obtaining an effective remedy in a cross-border context. ${ }^{56}$ The way in which the current framework shapes the litigants' strategies in cross-border EU competition law actions may be demonstrated by a number of cases $^{57}$ where the issue of jurisdiction has been subject to heated debates as well as by a recent case ${ }^{58}$ in which Article 6(3)(b) of the Rome II Regulation and the relevant limitation periods were central to the defendants’ unsuccessful strike-out application.

Secondly, the case law does suggest that there may be an even wider room for tactical manoeuvring in cross-border family law disputes, in which the economic consequences of divorce are at stake in court. This was explicitly acknowledged by Mr Justice Mostyn who stated that:

“[...] the Brussels 2 regulation, in my view, certainly permits forum shopping. It could be argued that it encourages forum shopping, inasmuch as it does not contain, in relation to a suit for divorce, a provision to transfer the suit to a court better placed to hear the case unlike proceedings in relation to children, where such a provision exists under Article 15 [...].”59

If an EU Member State court is not prepared to apply foreign substantive law in crossborder matrimonial disputes, then the financial remedies in such cases will be pre-determined by establishing jurisdiction in one Member State rather than another. This may be an important factor in cross-border cases because an English court will normally not apply foreign law/s in cross-border family law disputes. However, even in England, the need for factoring in the implications of a foreign matrimonial regime in cross-border family law disputes was acknowledged by the Court of Appeal in Radmacher $v$ Granatino $^{60}$ where Lord Justice Thorpe held:

"the judge should give due weight to the marital property regime into which the parties freely entered. This is not to apply foreign law, nor is it to give effect to a contract foreign to English tradition. It is, in my judgment, a legitimate exercise of the very wide discretion that is

\footnotetext{
${ }^{55}$ Directive 2014/104/EU on Antitrust Damages Actions.

${ }^{56}$ See M. Danov and F. Becker, 'Governance Aspects of Cross-Border EU Competition Law Actions: Theoretical and Practical Challenges’, 10 Journal of Private International Law (2014), p. 359-401. See also: I. Lianos, P. Davis and P. Nebbia, Damages Claims for the Infringement of Competition Law (OUP, Oxford 2015) p, 374.

${ }^{57}$ Roche Products Limited, Roche Vitamine Europe AG (Switzerland), F. Hoffmann-La Roche AG (Switzerland) $v$ Provimi Limited [2003] EWHC 961 (Comm); SanDisk Corporation v Koninklijke Philips Electronics and others [2007] EWHC 332 (Ch), [2007] Bus LR 705; Cooper Tire \& Rubber Company v Shell Chemicals UK Limited [2009] EWHC 2609 (Comm); Cooper Tire \& Rubber Company Europe Limited \& Others [2010] EWCA Civ 864; Toshiba Carrier UK Ltd and Other v KME Yorkshire Limited \& Others [2011] EWHC 2665 (Ch); Toshiba Carrier UK Ltd and Other v KME Yorkshire Limited \& Others [2012] EWCA Civ 169; Ryanair Ltd v Esso Italiana Srl [2013] EWCA Civ 1450.

${ }^{58}$ DSG Retail Ltd \& Ors v Mastercard Incorporated \& Ors [2015] EWHC 3673 (Ch).

${ }^{59}$ CC v NC [2014] EWHC 703 (Fam) [14].

${ }^{60}$ Katrin Radmacher (formerly Grantino) v Nichola Joseph Jean Jean Granatino [2009] EWCA Civ 649.
} 
conferred on the judges to achieve fairness between the parties [...]." 61

There is certainly a need for a fairer solution for litigants in a cross-border context. The approach endorsed by Lord Justice Thorpe is somewhat in line with PIL theory, making a case for "special substantive rules for multistate problems" 62 which were so thoughtfully considered by Von Mehren ${ }^{63}$ over 40 years ago. However, the UK Supreme Court did not go that far in the Radmacher case. The majority decision said that:

"In summary, the issues in this case are governed exclusively by English law. The relevance of
German law and the German choice of law clause is that they clearly demonstrate the intention
of the parties that the ante-nuptial agreement should, if possible, be binding on them" 64

Therefore an improvement in the account given to foreign law agreed to by the parties in the family law area will require legislative changes in the UK.

Thirdly, there could be multiple (and often expensive) proceedings between the same parties in cases where the parties had not considered the importance of the relationship between the laws of the forum and the available financial remedies in cross-border matrimonial disputes. This point may be illustrated by making reference to the judgment of the English High Court in $A A v B B .{ }^{65}$ In this case, the English proceedings were initiated under the Maintenance Regulation. The wife sought financial remedies in respect of a marriage which was dissolved in Slovenia on $8^{\text {th }}$ November 2011 . The parties to the proceedings were both born in Kosovo. In 1991, they moved to live in Slovenia where they remained until 2008, when the wife and the children moved to England. The parties had to litigate in both England and Slovenia because "the Slovenian court ha[d] no jurisdiction to deal with the parties' assets located outside Slovenia.” ${ }^{66}$ The point was noted by Mrs Justice King who stated that "the parties are in the unfortunate position of having to litigate in two countries. That, however, is a consequence of the limitation of the Slovenian court's powers.” 67

Therefore, given the level of diversity across the EU, a major feature of the EU legal landscape is the triangular relationship between the allocation of jurisdiction and

\footnotetext{
${ }^{61}$ Ibid [53].

${ }^{62}$ A. T. von Mehren, 'Special Substantive Rules for Multistate Problems: Their role and significance in contemporary choice of law methodology’ (1974-1975) 88 Harvard Law Review 347.

${ }^{63}$ Ibid.

${ }^{64}$ [2010] UKSC 42, para 108 (Lords Phillips, Hope, Rodger, Walker, Brown, Collins and Kerr). Lady Hale in a minority judgment also limited the relevance of the foreign element but in a slightly different way: "The relevance is not as to the effect of a foreign agreement in English law because, by the time the case gets to the divorce court, it has none. The relevance is as to the parties' intentions and expectations at the time when they entered into it.” (para 183).

${ }^{65}$ AA $v B B$ [2014] EWHC 4210 (Fam).

${ }^{66}$ Ibid [25].

${ }^{67}$ Ibid [89].
} 
identification of applicable law, on the one hand, and the available remedy, on the other hand. With this in mind, a definition of the concept of justice in the EU presupposes finding a response to the following question: What is "the impact of social facts on the development, operation and effect of legal rules” ${ }^{68}$ which form part of the harmonised EU PIL instruments? In his analysis of the sociological dimensions of private international law, Zweigert has noted:

\begin{abstract}
"If you go through the classical principles of conflict of laws, you will detect very few rules where the impact of social facts, some substantive points of view, are involved. The strongest substantive point of view is to be found in the institution of public policy. This is, however, a purely negative point of view which denies the whole play of conflict rules in exceptional cases; where an applicable rule is not applied because it offends too strongly indispensable values of the lex fori." 69
\end{abstract}

That said, an entirely different set of objectives characterises the current EU civil justice framework. As already noted, the right to an effective remedy appears to be at the heart of the EU Justice Agenda 2020 and the newly adopted Brussels I Recast Regulation which puts them in line with the EU Charter of Fundamental Rights.

Moreover, the Brussels I Recast Regulation, for the first time, sets out "the aim of making cross-border litigation less time-consuming and costly". ${ }^{70}$ Such an EU objective strongly suggests that it is very important for an effective remedy to be awarded without delay at reasonable cost in cross-border cases. The latter deduction could be strengthened by noting that the Brussels I Recast does now inter alia aim to "avoid abusive litigation tactics" ${ }^{71}$ which may further inflate the litigation costs, flying in the face of the EU policymakers' objective to provide an effective remedy in such cases. With this in mind, one should note that the Brussels Ia, Brussels IIa, Rome I, Rome II and the Maintenance Regulations (once regarded as a legislative package which implements the EU policy objectives in the area) appear to pursue the following objectives: (1) to set up jurisdictional rules which are unified $^{72}$ and highly predictable; ${ }^{73}$ (2) to create effective mechanisms dealing with parallel

\footnotetext{
${ }^{68}$ K. Zweigert, 'Some Reflections on the Sociological Dimensions of Private International Law or What is Justice in Conflict of Laws’ (1972-1973) 44 University of Colorado Law Review 283, 290.

${ }^{69}$ Ibid. 291.

${ }^{70}$ Recital 26 of Brussels I Recast Regulation.

${ }^{71}$ Recital 22 of Brussels I Recast Regulation.

${ }^{72}$ Recital 4 of Regulation (EU) No 1215/2012 of the European Parliament and of the Council of 12 December 2012 on jurisdiction and the recognition and enforcement of judgments in civil and commercial matters (Brussels I Recast Regulation), [2012] OJ L 351/1 . See also: Recital 12 of Council Regulation (EC) No 2201/2003 of 27 November 2003 concerning jurisdiction and the recognition and enforcement of judgments in matrimonial matters and the matters of parental responsibility, repealing Regulation (EC) No 1347/2000 (Brussels IIa Regulation), [2003] OJ L 338/1.

${ }^{73}$ Recital 15 of Brussels I Recast Regulation.
} 
proceedings; ${ }^{74}$ (3) to ensure that the same law is applied regardless of which court in the EU hears the case (while recognising that this objective will only be followed by some Member States in relation to family law matters) ${ }^{75}$ and (4) to ensure that judgments given in a Member State are swiftly recognized and enforced across Europe. ${ }^{76}$

It could be argued that if the foregoing objectives were not effectively pursued, the whole EU justice framework would be ineffective because a number of parties who need a remedy in a cross-border context may decide that the risks of litigation outweigh the benefits. ${ }^{77}$ It could be further questioned whether there would be effective remedies for all litigants in cross-border cases across the EU, if the EU Member States (or some of the Member States courts) are not in position to consistently and swiftly apply the Brussels Ia, Brussels IIa, Rome I, Rome II and Maintenance Regulations. This poses the following questions: How is justice administered in cross-border cases in the EU? How ought it to be administered in theory?

\section{THEORETICAL CHALLENGES: ADMINISTRATION OF JUSTICE IN THE EU}

Devising an appropriate EU institutional framework would be very important, in order to shape the development of the PIL instruments in a way which allows for the effective administration of justice in cross-border cases. The Stockholm programme expressly provides that " $[\mathrm{t}]$ he achievement of a European area of justice must be consolidated so as to move beyond the current fragmentation. Priority should be given to mechanisms that facilitate access to justice, so that people can enforce their rights throughout the Union." ${ }^{78}$ In this context, one should consider the multi-level "governance" ${ }^{79}$ model which is central to the

\footnotetext{
${ }^{74}$ Recital 21of Brussels I Recast Regulation.

${ }^{75}$ Recital 6 of Rome II, Recital 6 of Rome I, Recital 3 of the EC Council Decision Concluding the Hague Maintenance Protocol and Recital 9 of Rome III.

${ }^{76}$ Recital 4 of Brussels I Recast Regulation. See Article 19 of Brussels IIa Regulation.

${ }^{77}$ See the economic literature: J. A. Ordover, 'Costly litigation in the model of single activity accidents' 7 (1978) Journal of Legal Studies 243; See S. Shavel, 'Suit, settlement and trial: A theoretic analysis under alternative methods for the allocation of legal cost' (1982) 11 Journal of Legal Studies 55; S. Shavel, 'The social versus the private incentives to bring suit in a costly legal system' (1982) 11 Journal of Legal Studies 333; H.S.E. Graville, 'The Efficiency Implications of Cost Shifting Rules’ (1993) 13 International Review of Law and Economics 3; C. F. Beckner III and A. Katz, 'The Incentive Effects of Litigation Fee Shifting When Legal Standards Are Uncertain’ (1995) 15 International Review of Law and Economics 205.

78 The Stockholm Programme, - An open and secure Europe serving and protecting the citizens [2010] OJ C115/1, 4 and 11-2.

${ }^{79}$ It has been submitted that 'The term 'governance' is used in relation to national, European and international orders, and it crosses the public-private divide. (...) Governance (...) encompasses all stages of the policy chain, from drafting to enacting to implementing to enforcing rules.' M. De Visser, Network-Based Governance in EC
} 
successful implementation of the Union's policies in private law as well as to the effective functioning of the EU civil justice framework. The European Commission ${ }^{80}$ has identified the five principles, which would be essential for a good governance system, as being “openness, participation, accountability, effectiveness and coherence." 81

The principles of effectiveness and coherence are very important for designing a wellfunctioning EU civil justice system which presupposes that all the 28 Member States' courts will effectively and consistently apply a number of harmonised PIL instruments adopted at EU level. The private international law theory indicates that the EU civil justice system could only achieve its objectives, if the adopted PIL instruments are "uniformly administered" 82 across the EU. However, the Union does not have a "unified and centralized administration of justice” ${ }^{83}$ in disputes with an international element arising in the EU. Since there is no supranational court ${ }^{84}$ which hears and determines all the jurisdictional disputes in the EU, the Union relies on the EU Member States' national systems to dispense justice in cross-border cases. In other words, the national courts may be regarded as Union courts, ${ }^{85}$ when assuming jurisdiction and applying the EU PIL instruments.

Bearing in mind the fact that the PIL instruments are the foundation of the EU civil justice system, the "institutional arrangements and traditions that we have" ${ }^{86}$ in the European

Law (Hart Publishing, 2009), p. 4. See more: C. Joerges, 'European challenges to private law: On false dichotomies, true conflicts and the need for a constitutional perspective’, 18 Legal Studies (1998), p. 146; C. Joerges, 'The impact of European integration on private law: Reductionist perceptions, true conflicts and a new constitutional perspective’, in C. Joerges and O. Gerstenberg (eds.), COST A7 - Private governance, democratic constitutionalism and supranationalism (Office for Official Publications of the European Community, 1998), p. 69.

${ }^{80}$ The European Commission, European Governance - A White Paper, COM(2001) 428 final.

${ }^{81}$ Ibid. 10. See also: The New Modes of Governance Project - T. L. Brunell, C. Harlow, A. S. Sweet, 'Litigating the Treaty of Rome: The European Court of Justice and Articles 226, 230, and 234' < http://www.eunewgov.org/datalists/deliverables_detail.asp?Project_ID=26 > (last visited 10 June 2013); K. Armstrong, 'The character of EU law and governance: From “Community method” to new modes of governance’ (2011) 64 Current Legal Problems 179.

${ }^{82}$ A. T. von Mehren, 'Choice of law and the problem of justice' (1977) 41 Law \& Contemporary Problems 27, 32.

${ }^{83}$ A. T. von Mehren, 'Choice of Law and the Problem of Justice' (1977) 41 Law and Contemporary Problems $27,28$.

${ }^{84}$ M. Kahler and D. A. Lake, 'Economic Integration and Global Governance: Why so little supranationalism?' in W. Mattli and N. Woods (eds), The Politics of Global Regulation (Princeton University Press, Princeton 2009) 242. See also: R. H. Graveson, 'Problems of Private International Law in Non-Unified Legal Systems' in R. H. Graveson, Comparative Conflict of Laws: Selected Essays (Vol 1, North-Holand Publishing, Amsterdam 1977) 305, 337.

${ }^{85}$ P. Craig, 'The Jurisdiction of the Community Courts Reconsidered' in G. de Burca and J. H. H. Weiler (eds), The European Court of Justice (OUP, Oxford 2001) 177, 178. See also: J. Komarek, 'Federal Elements in the Community Judicial System: Building Coherence in the Community Legal Order' (2005) 42 CMLRev 9, 10 ; J. Komarek, 'In the court(s) we trust? On the need for hierarchy and differentiation in the preliminary ruling procedure' (2007) ELRev 467, 468.

${ }^{86}$ A. T. von Mehren, 'Conflict of Laws in a Federal System: Some Perspectives' (1969) 18 International and Comparative Law Quarterly 681, 684. 
Union must be considered with a view to effectively administering justice in the EU. The problem of consistent application of the harmonised PIL instruments would be particularly acute because the EU has now expanded to integrate not only a number of Member States representing the two major legal traditions - the common law and the civil law, ${ }^{87}$ but also some of the former communist countries. De Boer has noted that an important "factor reducing the effectiveness of uniform law - private international law [...] - is the possible disparity in interpretation. [...] It must be feared that uniform law is doomed to be nationalized.” ${ }^{88}$ It has been also argued that if there is no "certain affinity between the legal systems amongst which unification is to be achieved [...], the provisions of the uniform laws run the risk of being substantially altered when they are adapted to the various internal legal systems." ${ }^{89}$ In view of that, one could submit that the use of harmonised PIL instruments could raise the level of uncertainty/ambiguity and inflate both public and private litigation costs, posing particular challenges for national judges and litigants in private disputes with an international element.

Therefore, the role of Member States' courts is particularly important for the resolution of disputes with an international element arising in the European Union context. The way the national courts apply the PIL instruments is of primary importance for the effective administration of justice in cross-border cases in the EU. It should be noted that Rawls had submitted that "the conception of formal justice, the regular and impartial administration of public rules, becomes the rule of law when applied to the legal system." 90 Two of the key features of a legal system were defined by Rawls as: the existence of rules which are directly applicable and have direct effect; and the existence of adequate enforcement mechanisms because "[l]aws and commands are accepted as laws and commands only if it is generally believed that they can be obeyed and executed." 91

Difficulties may arise because the EU relies on individual Member States' legal orders, which share different legal traditions and heritages, to uniformly apply its harmonised PIL instruments that are adopted at EU level. The national judges across the EU would have to “interpret and apply a fairly large set of [EU PIL rules] in a sufficiently harmonised

\footnotetext{
${ }^{87}$ P. Legrand, ‘Against a European Civil Code’ (1997) 62 Modern Law Review 44.

${ }^{88}$ T. de Boer, 'The relation between uniform substantive law and private international law' in A. S. Hartcamp [et al.] Towards a European Civil Code (Martinus Nijhoff, 1994) 51, 59.

${ }^{89} \mathrm{M}$. Matteucci, 'The Methods of the Unification of Law' in Unidroit International Institute for the Unification of Private Law, Unification of Law (Volume 2, UNIDROIT, Rome 1957) 87.

${ }^{90}$ J. Rawls, Theory of Justice - Revised Edition (OUP, Oxford 1999) p 206

${ }^{91}$ Ibid p 208. Compare: T. C. Hartley, 'National Law, International Law and EU Law - How Do They Relate?' in P. Capps, M. Evans and S. Konstadinidis (eds), Asserting Jurisdiction: International and European Legal Perspectives (Hart Publishing, Oxford 2003) 65, 70.
} 
manner" 92 which is a major challenge in the already very enlarged European Union. The level of diversity across the Union indicates that there a number of problems which one should consider when considering the administration of justice in cross-border cases in the EU. First, some national judges might be naturally biased and interpret the PIL instruments in a way which allows them to assume jurisdiction and apply their national laws. Secondly, Member States' courts might give different interpretations to the harmonised private international law instruments.

One may disagree with such a deduction by noting that Member States' judges are empowered to make reference requests to the Court of Justice of the European Union for preliminary rulings, regarding the interpretation of the PIL instruments, under Article 267 TFEU. ${ }^{93}$ However, the CJEU preliminary reference procedure is not without problems which may be adversely affecting the legal landscape in the European Union. First, the timeline within which the CJEU would opine on the PIL issues means that there could often be a further level of delay and significant costs for the parties who seek to obtain a remedy in cross-border cases. The most recent statistics data from the CJEU does suggest that "[i]n the case of references for a preliminary ruling, the average duration amounted to 15 months, which is a record.” ${ }^{94}$ Although the CJEU can be proud of this achievement, the problem would be significant in cross-border cases where the preliminary ruling had been made on an issue of jurisdiction, indicating that the merits of the disputes were, most likely, not even considered at this stage. Second, bearing in mind the level of delay, some of the Member States’ judges may be reluctant to make such reference unless absolutely necessary. ${ }^{95}$

In spite of the possibility for the EU Member States' court to make preliminary references to the CJEU, the diverse legal landscape in the European Union indicates that the jurisdictional divergences may make a difference for litigants, seeking to obtain an effective remedy in an enlarged European Union. As a result, private parties (especially parties that are able to cover the high litigation costs, affording sophisticated legal advice) may become very selective when deciding where to sue in cross-border cases. Therefore, when it comes to the

\footnotetext{
${ }^{92}$ L. Tichy, 'A new role for private international law and procedural law in European Integration? A critical comment' in R. Brownsword, H-W. Micklitz, L. Niglia and S. Weatherill (eds), The Foundations of European Private Law (Hart Publishing, Oxford 2011) 393, 412.

${ }_{93}$ Case 283/81 CILFIT [1982] ECR 3415.

${ }^{94}$ Court of Justice of the European Union, Press Release No 27/15, Luxembourg, $3^{\text {rd }}$ March 2015. See also: Court of Justice of the European Union, Annual Report 2014, Luxembourg 2015.

${ }^{95}$ E.g. I (A Child) (Contact Application: Jurisdiction), Re [2009] UKSC 10 [35, 76 and 92]; Cooper Tire and Rubber Co Europe Ltd v Shell Chemicals UK Ltd [2010] EWCA Civ 864 [46]; Mv M [2013] EWCA Civ 1255 [50]; Canyon Offshore Ltd v GDF Suez E\&P Nederland BV [2014] EWHC 3801 (Comm) [54]; Lady Christine Brownlie v Four Seasons Holdings Incorporated [2015] EWCA Civ 665 [92].
} 
administration of justice in the EU, the triangular relationship, allocation of jurisdiction identification of governing law - the available remedy, would further encompass the ability of the Member States' courts to deal with cross-border disputes. The latter factor may be important for the forum selection process which may have significant implications for the current model for administration of justice in cross-border cases.

That said, there is a recent view ${ }^{96}$ that national policies in promoting certain jurisdictions as leading litigation centres may have a bearing on the interpretation of the EU PIL by the courts. In particular, it has been recently stated that:

\footnotetext{
"The substantial economic flows generated by commercial litigation justify the existence of a longstanding national policy promoting the UK - and London in particular - as a capital for international dispute resolution. [...]

Choice of law is not alien to this concern. It was mentioned above that the law applicable to the transaction can play an important role in the determination of jurisdiction, particularly when the test is conducted under common law rules.”, 97
}

This view is a very controversial one because, despite any campaign undertaken by the UK Ministry of Justice ${ }^{98}$ and/or the Law Society, ${ }^{99}$ one should not forget that the EU PIL instruments are applied by the national judges. The judiciary is indeed independent in the UK. Furthermore, as Fons himself acknowledges, the "policy [promoting London as a litigation capital] has never been spelt out in English judgments.” ${ }^{100}$ In spite of that, Fons has argued that “[t]he data provided in [his] study supports [the] theory that an 'open door policy' might have underpinned many of the choice of law determinations by English courts under the Rome instruments." ${ }^{101}$ However, a closer look at the data shows that the research findings in question are based on 66 cases, ${ }^{102}$ which were dealt with by the English courts for a period of nearly 20 years. Drawing on a small sample of the highly contested cases that had been decided over a period of nearly 20 years, and concluding that "the overarching economic policy prevails [...] and pervades the application of the European choice of law

\footnotetext{
${ }^{96}$ M. P. Fons, 'Commercial Choice of Law in Context: Looking Beyond Rome' (2015) 78 Modern Law Review 241-295. Compare a similar view expressed in a different context by J. J. Fawcett, 'Trial in England or Abroad: The Underlying Policy Considerations’ (1989) 9 Oxford Journal of Legal Studies 205, 218.

${ }^{97}$ Ibid. 259-260.

${ }^{98}$ UK Ministry of Justice and UK Trade and Investment, Plan for Growth: Promoting the UK's Legal Services Sector - 30 ${ }^{\text {th }}$ March $2012<$ https://www.justice.gov.uk/downloads/publications/corporate-reports/MoJ/legalservices-action-plan.pdf $>$.

${ }^{99}$ The Law Society of England and Wales, England and Wales: The Jurisdiction of Choice < http://www.eversheds.com/documents/LawSocietyEnglandAndWalesJurisdictionOfChoice.pdf > . The initiative appears to be sponsored by Herbert Smith, Norton Rose and Eversheds.

${ }^{100}$ M. P. Fons, 'Commercial Choice of Law in Context: Looking Beyond Rome’ (2015) 78 Modern Law Review 241, 260.

${ }^{101}$ Ibid. 263

${ }^{102}$ Ibid 279.
} 
instruments" 103 is like "generalizing about war from the details of the most bloody and hard fought battles.” 104

Therefore, an appropriate research methodology is needed with a view to properly addressing the theoretical challenges, whilst identifying the factors that influence the parties' decision where to sue in a cross-border dispute. Indeed, there is a case that the Brussels Ia, Brussels IIa and Maintenance Regulations, which largely adopt a 'court-first-seised' rule and provide claimants with a choice where to bring their claims, could well promote adjudicatory jurisdiction competition. That said, an EU model of administration of justice, which allows litigants to choose where to litigate, may gradually transform a mode of governance - based on "networks" ${ }^{105}$ (implementing the principle of mutual trust in the EU) - into an entirely different model which could be based on "hierarchy”, 106 with some EU Member States' courts becoming more attractive than others. This would be so because the jurisdictions, attracting more cross-border cases, will become dominant, being a venue of choice for the high value cross-border disputes which would often involve highly sophisticated parties. This is something which is already happening in cross-border EU competition law cases where the majority of claims are being brought in England and Wales, the Netherlands and Germany. ${ }^{107}$

A competition among the different judicial regimes could be driven by large law firms (and increasingly by litigation funders ${ }^{108}$, perhaps) which may be seen as the catalyst for the change in the EU model of administration of justice. As a result, the judges in some EU Member States more often have to decide cases with an international element, gaining more experience than the judges in the other Member States in dealing with cross-border disputes. These developments may better explain why some judicial systems may become more attractive for litigants than others. For example, remedies could be obtainable more quickly in jurisdictions where settlements could be easily achieved after jurisdiction had been established there. Indeed, an OECD report ${ }^{109}$ and the 2015 EU Justice Scoreboard ${ }^{110}$ both re-

\footnotetext{
103 Ibid 263.

${ }^{104}$ H. Genn, 'Preliminary Analysis of Costs Data’, Review of Civil Litigation Costs, Seminar 26 June $2009<$ https://www.ucl.ac.uk/laws/judicialinstitute/events/Jackson_Costs_Review_Preliminary_Analysis_of_Costs_Data_pdf $>$ (accessed $4^{\text {th }}$ Jan 2016). ${ }^{105}$ M. Kahler and D. A. Lake, 'Economic Integration and Global Governance: Why so little supranationalism?' in W. Mattli and N. Woods (eds), The Politics of Global Regulation (Princeton University Press, Princeton 2009) 242

106 Ibid.

${ }^{107}$ Executive Summary of the Impact Assessment, SWD(2013) 204 final, para. 7.

${ }^{108}$ N Rowles-Davies and J Cousins, Third Party Litigation Funding (OUP, Oxford 2014).

${ }^{109}$ G. Palumbo and others, 'The Economics of Civil Justice: New Cross-country Data and Empirics' (2013)

OECD Economics Department Working Papers, No. 1060, OECD Publishing < http://dx.doi.org/10.1787/5k41w04ds6kf-en >

${ }^{110} \mathrm{COM}(2015) 116$ final.
} 
affirm that there is a level of variation in the performance of the various judicial systems across the European Union. In particular, the trial length and appeal rates do vary; the models of court governance and the relevant budgets are different. ${ }^{111}$ Therefore, the length of the court proceedings may be an important factor to be taken into account when considering as to how justice should be administered in cross-border cases arising in the EU. In England, Zuckerman has noted:

\begin{abstract}
"It is not enough to ask whether the system produces correct judgments. We have also to ask how timely judgments are, because a judgment given too late may amount to denial of justice even though it involves correct application of the law to true facts. Cost too is relevant to the assessment of procedural systems. The resources available to the system will influence its global level of rectitude of decision. Cost will influence its global level of rectitude of decision. Cost will affect access to justice and, lastly, high litigation costs may enable rich litigants to acquire a procedural advantage against their opponents.

Each of these aspects is clearly relevant to the assessment of any system of civil justice.”. 112
\end{abstract}

In other words, Zuckerman's observations strongly suggest that issues of “delay” and "costs" are two important factors which any system for effective administration of justice would need to consider. It should be noted that a comparative study, ${ }^{113}$ which was conducted by a research consortium, has addressed "how different jurisdictions approach the two linked subjects of litigation funding and costs." ${ }^{114}$ Thus, the EU Member States could well have legitimate incentives to make their national systems functioning effectively, which would allow their law firms to attract litigants from other EU Member States, exporting cross-border legal services.

How do the cross-border complexities/implications of claims affect the litigants' strategies of the parties and the settlement dynamics in the EU? Hartley ${ }^{115}$ has recently noted that:

\footnotetext{
"the outcome of a case depends much more on jurisdiction than choice of law. This has become clearly apparent, at least in leading centres of litigation, in recent times. It explains why the parties will fight tooth and nail on jurisdictional issues; then, once these are decided, settle the case without further litigation. This in turn accounts for the fact that in England today there are far more reported cases on international jurisdiction and procedure than on choice of law.” 116
}

\footnotetext{
${ }^{111}$ G. Palumbo and others, 'The Economics of Civil Justice: New Cross-country Data and Empirics' (2013) OECD Economics Department Working Papers, No. 1060, OECD Publishing < http://dx.doi.org/10.1787/5k41w04ds6kf-en >.

${ }^{112}$ A. A. S. Zuckerman, 'Justice in crisis: Comparative dimensions of civil procedure' in A. A. S. Zuckerman (ed), Civil Justice in Crisis: Comparative perspectives of Civil Procedure (OUP, Oxford 1999) 3, 10-1.

${ }^{113}$ C. Hodges, S. Vogenauer and M. Tulibacka (eds.), The Costs and Funding of Civil Litigation: A Comparative Perspective (CH Beck and Hart, Oxford 2010).

${ }^{114}$ C. Hodges, S. Vogenauer and M. Tulibacka, 'Introduction’ C. Hodges, S. Vogenauer and M. Tulibacka (eds.), The Costs and Funding of Civil Litigation: A Comparative Perspective (CH Beck and Hart, Oxford 2010) 3.

${ }^{115}$ T. C. Hartley, International Commercial Litigation (2 ${ }^{\text {nd }}$ edn, CUP, Cambridge 2015).

${ }^{116}$ Ibid. pp 5-6.
} 
The quoted view is indeed interesting, but not fully substantiated, indicating that further empirical evidence is needed in the EU context. On the one hand, the empirical evidence from the U.S. clearly demonstrates that "forum does affect outcome".. ${ }^{117}$ Similarly in the EU the empirical research project on Cross-Border EU Competition Law Actions ${ }^{118}$ appears to support Hartley's view that litigants regard the procedural aspects as an important factor when deciding where to sue. Indeed, tactical jurisdictional challenges and settlements are very common in cross-border EU competition law disputes. ${ }^{119}$

On the other hand, it is well established that, in England, many cases settle before trial even in a domestic context. ${ }^{120}$ Hence, the parties may embark on the jurisdictional battles because they want (or do not want, as the case may be) to establish jurisdiction in England where most of the cases settle, anyway. However, achieving a settlement, after jurisdiction had been established, would not necessarily mean that the choice-of-law rules were not important (or less important) for the outcome. It simply could be that the governing law aspects were factored into the settlement negotiations. In other words, empirical evidence is needed with a view to identifying the factors which lead the cross-border cases to settle.

That said, there may be significant methodological challenges, which need to be considered. A recent empirical study ${ }_{-}^{121}$ (involving questionnaires being sent out to legal practitioners) demonstrates that there are various difficulties and multiple factors which appear to pose problems for parties, on the one hand, and drive the settlement behaviour in competition cases, on the other hand. In this context, when discussing the difficulties for the parties to bring a case and when comparing it to the factors which encourage settlements in the UK, Rodger identified the following methodology hurdles:

\footnotetext{
${ }^{117}$ K. M. Clermont and T. Eisenberg, 'Do case outcomes really reveal anything about the legal system? Win rates and removal jurisdiction' (1997-1998) 83 Cornell Law Review 581, 607. See also K. M. Clermont, 'Jurisdictional Salvation and the Hague Treaty' (1999) 83 Cornell Law Review 89, 108-109, W. E. O’Brian Jr, 'The Hague Convention on Jurisdiction and Judgments: The Way Forward' (2003) 66 Modern Law Review 491, 497.

${ }^{118}$ M. Danov, F. Becker and P. Beaumont, Cross-Border EU Competition Law Actions (Hart Publishing, Oxford 2013)

${ }^{119}$ S. Salop and L. White, "Private Antitrust Litigation: An Introduction and Framework” in L. White (ed), Private Antitrust Litigation, New Evidence, New Learning (MIT Press, Cambridge, Mass 1988) 1, 23. See also: B. Rodger, "Private enforcement of competition law, the hidden story: competition litigation settlements in the United Kingdom, 2000-2005”, (2008) 29 European Competition Law Review 96. See also: B. Rodger, “Competition law litigation in the UK courts: a study of all cases 2005-2008: Part I”, (2009) 2 GCLR 93; B. Rodger, "Competition law litigation in the UK courts: a study of all cases 2005-2008: Part II", (2009) 2 GCLR 136; B. Rodger, "Private enforcement of competition law, the hidden story: Part II: competition litigation settlements in the United Kingdom, 2008-2012”, (2015) 8 GCLR 89-108.

${ }^{120}$ H. Genn, Judging Civil Justice (CUP, Cambridge 2010) p 21. See the Civil Justice quarterly statistics < https://www.gov.uk/government/collections/civil-justice-statistics-quarterly > .

${ }^{121}$ B. Rodger, "Private enforcement of competition law, the hidden story: Part II: competition litigation settlements in the United Kingdom, 2008-2012” (2015) 8 GCLR 89
} 
“[...] the responses make it difficult to relate particular cases and types of disputes to specific difficulties. [e.g.] Legal uncertainty was cited as a difficulty in 15 cases overall (33.3 per cent) although strangely not all of the cases match with those where the uncertainty of litigation was considered to be a factor motivating settlement (in 33 cases, 73.3 per cent). [...]" 122

Therefore, bearing in mind the nature of the empirical evidence which is needed, an appropriate research methodology ${ }_{-}^{123}$ is central to successfully determining how the EU model of administration of justice is functioning in the EU.

\title{
METHODOLOGICAL CHALLENGES: MEASURING THE EFFECTIVENESS OF THE EU CIVIL JUSTICE SYSTEM
}

In the light of the objectives of the EU civil justice system, the first methodological challenge was to specify what empirical evidence is necessary to test the effects of the harmonised PIL instruments on the litigation strategies of those who need a remedy in cross-border cases. ${ }^{124}$ It has been submitted that:

\begin{abstract}
"Although there are many ways in which outputs and outcomes assessment can be conducted, these methodological options are not all equivalent: some produce more credible estimates of policy effects than others. Therefore, it is not surprising that there is still a deep divide and fierce academic struggle among the advocates of quantitative versus qualitative methods of policy evaluation.” ${ }^{125}$
\end{abstract}

Accordingly, in terms of research design, an important methodological aspect concerns the question what research methods (or what mix of research methods) are to be used. In view of the foregoing, the authors' view is that one should measure the effectiveness of the EU civil justice framework after collecting data for the following aspects of cross-border litigation: What are the most common types of cross-border disputes (e.g. contractual, tortious, child abduction, parental responsibility)? What are the most common remedies sought in a cross-border context? What are the factors that private parties consider when deciding whether and where to sue in cross-border cases? How does the court-first-seised rule shape the litigants' strategy in cross-border cases? Is cross-border litigation more expensive than domestic litigation? What are the factors that affect the litigants' strategies and

\footnotetext{
${ }^{122}$ Ibid 100-1.

${ }^{123}$ See more: P. Cane and H. Kritzer (eds), The Oxford Handbook of Empirical Legal Research (OUP, Oxford 2012); L. Epstein \& A. D. Martin, An Introduction to Empirical Legal Research (OUP, Oxford 2014). ${ }^{124}$ Ibid 219-221.

${ }^{125}$ F. Varone, B. Rihoux and A. Marx, ‘A New Method for Policy Evaluation? Longstanding Challenges and the Possibilities of Qualitative Comparative Analysis (QCA)' in B. Rihoux and H. Grimm, Innovative Comparative Methods for Policy Analysis (Springer, 2006) 213, 213-4.
} 
settlement dynamics in the different types of cross-border cases? ${ }^{126}$ How do the cross-border implications (which might include higher levels of uncertainty and higher litigation costs) of claims affect the suing decisions of the parties and settlement negotiations? What are the main factors that affect the settlement negotiations in cross-border cases?

Snyder's study on effectiveness puts forward that "[a] commonly used approach to the effectiveness of Community law is that of implementation theory." ${ }^{127}$ Hence, the way in which the harmonised PIL measures are applied by the Member States' courts must be considered in order to evaluate the effectiveness of the current private international law framework. Analyses of the Member States' case law must be undertaken. To this end, the authors will compile "datasets" ${ }^{128}$ for the cases before English and Scottish courts for the period since 1 March 2002 (entry into force of the Brussels I Regulation). The Member State datasets include the following information: the harmonised PIL instrument; the Member State court; the year when the proceedings were initiated; the remedy sought (declaratory, injunctive, monetary); the value of the claim; the domicile (or habitual residence) of the claimants which will enable us to measure the mobility of the claimants (e.g. corporations; SMEs; consumers; family members); the PIL issue raised and addressed (e.g. the relevant jurisdictional rule/s, the national law/s applied); important factors influencing the judgment (e.g. choice of court/law agreements etc); and the date of the judgment. Since the CJEU has an important role to play when it comes to the interpretation of the harmonised PIL instruments in Europe, another dataset for the preliminary references before the CJEU is being done. In the latter context, the researchers are using a similar research methodology to the one utilised by Sweet and Brunell in their "Note on the Data Sets: Litigating EU Law under the Treaty of Rome”." 129

The datasets should allow the researchers to engage with the relevant cases and identify the litigation pattern in Scotland, England and Wales. However, empirical evidence from

\footnotetext{
${ }^{126}$ J. E. Calfee and R. Craswell, "Some effects of uncertainty on compliance with legal standards" (1984) 70 Virginia Law Review 965; R. Craswell and J. E. Calfree, "Deterrence and uncertain legal standards” (1986) 2 Journal of Law, Economics and Organisation 279; A. M. Polinsky and S. Shavell, "Legal error, litigation and the incentive to obey the law" (1989) 5 Journal of Law, Economics and Organisation 99. See also: Danov and Dnes

${ }^{127}$ F. Snyder, 'The effectiveness of European Community law: Institutions, processes, tools and techniques' (1993) 56 Modern Law Review 19. See also: S. Krislov, C.-D. Ehlermann and J. Weiler, 'The political organs and the decision-making process in the United States and the European Community' in M. Cappelletti, M. Seccombe and J. Weiler, Integration Through Law: Europe and the American Federal Experience (Walter de Gruyter, Berlin 1986) pp 3 - 112.

${ }^{128}$ For those purposes, a dataset is defined as "a collection of data that someone has organised in a form that is susceptible to empirical analysis." See: L. Epstein \& A. D. Martin, An Introduction to Empirical Legal Research (OUP, Oxford 2014) p. 66.

129 See ref. number: LTF II/D06a1.
} 
other Member States is also needed because there is a strong case that any research, seeking to identify what the appropriate direction of possible reforms would be, should consider how the EU private international law framework is functioning in countries representing different legal traditions in Europe. Social science researchers ${ }^{130}$ have recently noted that:

\begin{abstract}
"The methodological challenge is [...] to compare one (similar) European program, its implementation by domestic actors and its effects in a small $<<$ small-N $>>$ design, with a limited number of various countries, regions and/or administrations implementing the same (causal mechanism of the) European programme in various political, administrative, economic and social contexts. The methodological issue consists in identifying all the conditions (at the European level as well as at the domestic level) leading or not leading to the expected policy outputs and outcomes." 131
\end{abstract}

Belgium, England and Wales, Germany, Italy, Poland, Scotland and Spain have been deliberately, and not randomly, sampled. The purposive sampling has allowed us to include a range of jurisdictions (civil law, common law, mixed legal systems), having a large number of businesses as well as a large number of immigrants and/or emigrants. The quantitative data about the reported PIL cases from the sampled jurisdictions would be useful with a view to comparing the litigation pattern in cross-border cases brought in the sampled countries. Chalmers and Chaves ${ }^{132}$ have submitted that "[m]ost recent accounts accept that no single narrative fully explains European Union (EU) judicial politics [...]. Research will accordingly need to consider the conditions under which one narrative holds rather than another. Comparison of patterns of litigation or adjudication across sectors or from different territories will go some way towards answering this." ${ }^{133}$ Indeed, comparing the aspects which affect the litigants' strategies in various cross-border matrimonial disputes (where Rome III and the Hague Maintenance Protocol are not applicable in all Member States), on the one hand, and the litigants' tactics in cross-border civil and commercial interests would be important.

However, any quantitative data is bound to be insufficient for the purposes of a study measuring the effectiveness of the EU civil justice framework. First, it is well established that not all judgments rendered in cross-border cases will be reported or be accessible to researchers through electronic databases. Secondly, issues of jurisdiction and choice-of-law may not necessarily be subject to heated debates in all cross-border cases, so that some judgments in such cases may not refer to the relevant PIL instruments. ${ }^{134}$ Thirdly, any

\footnotetext{
${ }^{130}$ F. Varone, B. Rihoux and A. Marx, 'A New Method for Policy Evaluation? Longstanding Challenges and the Possibilities of Qualitative Comparative Analysis (QCA)' in B. Rihoux and H. Grimm, Innovative Comparative Methods for Policy Analysis (Springer, 2006) 213.

${ }^{131}$ Ibid. 224.

${ }^{132}$ D. Chalmers and M. Chaves, 'The reference points of EU judicial politics' in S. K. Schmidt and D. Kelemen (eds), The Power of the European Court of Justice (Routledge 2013) 25.

${ }^{133}$ Ibid.

${ }^{134}$ E.g, Emerald Supplies Ltd \& Others v British Airways v Air Canada \& Others [2014] EWHC 3513 (Ch).
} 
judgments on preliminary PIL issues are likely to be rendered in cases where the jurisdictional and/or choice-of-law aspects have been heavily contested by the parties. It may not be particularly helpful if the case for reform is based only on the highly contested PIL cases. Fourthly, it is well established that many cases settle before trial (or even before action) in England. ${ }^{135}$ Genn has noted:

\begin{abstract}
"Because claims are settled without any court formalities there is no official source of information about the claims settlement process. No records of settlements are publicly available, nor are there any official statistics relating to the volume of claims pursued and compromised, the level of settlements, or the costs involved in achieving settlements” 136
\end{abstract}

Therefore, it will be necessary to do a qualitative research project, turning to the views of legal practitioners. In this context, the researchers will need to test the effect of the harmonised PIL instruments by discussing with legal practitioners key questions concerning cross-border litigation. Accordingly, as a part of the project, the researchers will be undertaking qualitative interviews ${ }^{137}$ with legal practitioners. Legal practitioners are well placed to provide us with information about litigation strategies. ${ }^{138}$ The legal practitioners would have some useful insights as to how the current EU Civil Justice framework is shaping the litigants' strategies. In particular, some important issues which may need to be explored, as part of the qualitative interviews with legal practitioners, relate to the remedies sought, the level of legal uncertainty and the settlement dynamics in the cross-border context. Bearing in mind the EU legal landscape, it would be useful to identify the factors which affect the litigants' strategies and settlement dynamics in cross-border cases, making a difference between settlement as a tactical device in cases where an action has been initiated, on the one hand, and settlement as a dispute resolution mechanism which is used before an action has been started, on the other hand. Research studies,- ${ }_{-}^{139}$ undertaken in a domestic context, do suggest that "claimants significantly discount their claims in reaching mediated settlements. There is a price to pay in terms of substantive justice for early settlement." ${ }^{140}$ This might be even more of an issue in cross-border cases where the lengthy jurisdictional challenges would

\footnotetext{
${ }^{135}$ H. Genn, Judging Civil Justice (CUP, Cambridge 2010) p 21.

${ }^{136}$ H. Genn, Hard Bargaining: Out of Court Settlement in Personal Injury Actions (OUP, Oxford 1987) p 13.

${ }^{137}$ HJ Rubin and IS Rubin, Qualitative Interviewing: The Art of Hearing Data (Thousand Oaks CA, SAGE Publications, 1995) 3-4. See also: A. Bogner, B. Littig and W. Menz (eds), Interviewing Experts (Palgrave Macmillan 2009).

${ }^{138}$ S. C. Salop and L. J. White, 'Private Antitrust Litigation: An Introduction and Framework' in L. J. White (ed), Private Antitrust Litigation: New Evidence, New Learning (MIT Press, Cambridge 1988) 3, 16.

${ }^{139}$ H. Genn, Central London Pilot Mediation Scheme, Evaluation Report (Department for Constitutional Affairs, 1998) p. 71; L. Webley, P. Abrams and S. Bacquet, Evaluation of Birmingham Fast and Multi Track Mediation Scheme (Department for Constitutional Affairs) pp. 70-71.

${ }^{140}$ H. Genn, Judging Civil Justice (CUP, Cambridge 2010) p 113.
} 
inflate the cost of litigation which taken together with the level of uncertainty generated by the current institutional framework might force significantly discounted settlements.

Therefore, an appropriately conducted study would pre-suppose the collection of empirical evidence which will help to explain the litigation pattern in Europe. There is a need for such an empirical study to be conducted in several Member States, with different legal traditions/heritages, with a view to assessing the effectiveness of the current PIL institutional framework. This would allow the researchers to measure how the current PIL framework is affecting the litigants' strategies in different jurisdictions. ${ }^{141}$ That said, a main challenge in doing a comparative qualitative research project in law is recruiting interview participants from a number of jurisdictions, representing different legal systems.

Central to the process of conducting qualitative interviews with legal practitioners is drawing a sampling framework ${ }^{142}$ which is to be used when selecting interview participants. In this context, it should be noted that drawing a sampling framework in various jurisdictions should factor in the national characteristics. In addition, the researchers are conducting qualitative interviews with policy-makers from Brussels. The project examines possible proposals for the reform of the European Union Civil Justice system. The views of EU officials from Brussels are therefore very important; indeed, in view of the cross-border nature of the disputes any legislative reform is likely to be most effective at the EU level.. ${ }^{143}$

The non-schedule standardised (or unstructured schedule) ${ }^{144}$ type of interview is being employed for the purposes of this research project. This allows researchers to take into account the specific experience and the viewpoint of each respondent. A structure to the interviews is created, but the interviewer and/or interviewee is always free to depart from the structure if the participants’ viewpoints and experience were thereby better expressed. The interview questions focus on key areas: 1) General questions about cross-border disputes; 2) Interpretation of the EU Regulations; 3) Jurisdictional issues; 4) Applicable law issues; 5) Procedural issues; 6) Settlement 7) Alternative Dispute Resolution.

\footnotetext{
${ }^{141} \mathrm{~J}$. de Coninck, 'Comparisons in private patrimonial law: towards a bottom-up approach using (cross-cultural) behavioural economics' in in M. Adams and J. Bomhoff (eds), Practice and Theory in Comparative Law (CUP, Cambridge 2012) 258, 267.

${ }^{142}$ A. Wilmot, 'Designing sampling strategies for qualitative social research: with particular reference to the Office for National Statistics' qualitative respondent register' (2005), Paper on qualitative sampling strategies presented to QUEST 2005, Office of National Statistics < http://www.ons.gov.uk/ons/guide-method/methodquality/general-methodology/data-collection-methodology/reports-and-publications/index.html?format=print $>$ ${ }^{143}$ See Article 81 TFEU. See also: P. Beaumont and P. McEleavy, Private International Law, Anton ( $3^{\text {rd }}$ ed, SULI/W Green, Edinburgh 2011) pp. 16-17

${ }^{144}$ S.A. Richardson, B. S. Dohrenwend and D. Klein, Interviewing: its forms and functions (Basic Books, New York 1965) p. 45; R. K. Merton and P. L. Kendall, “The Focused Interview”, (1946) 51 American Journal of Sociology (1946), 541, 541-2; N. K. Denzim, The Research Act: A Theoretical Introduction to Sociological Methods (Prentice Hall, Englewood Cliffs, NJ 1989) 105.
} 
Due to the large data (quantitative and qualitative), the way the data is organised will be central to an effective and comparative data analyses. In this context, Bazeley has submitted:

\begin{abstract}
"Often, in funding proposals, there will be a lengthy description of how qualitative data are going to be gathered, but the only thing said about how these data are going to be managed or analysed is that 'themes will be identified in the data'. Similarly, writers of journal articles often simply identify and discuss four or five 'themes' as their analysis of the qualitative data in the study, with no attempt to link these themes into a more comprehensive model of what they have found.” 145
\end{abstract}

In view of this, the authors carefully planned how the data should be organised. The following pre-determined themes were considered important with a view to organising and analysing data: 1) Parties (e.g. legal entities, individuals) and their relationship (e.g. contractual, non-contractual, matrimonial); 2) Remedies and their value; 3) Legal landscape (e.g. first-seised-rule, different procedures, different length of proceedings, preliminary rulings); 4) Litigants strategies (e.g. where to sue, jurisdictional challenges, negative declarations, parallel proceedings, legal uncertainty, costs, legal aid, litigation funders); 5) Settlement dynamics - factors (e.g. cost shifting, level of uncertainty) affecting the settlement negotiations and the use of ADR mechanisms. The data analysis should allow researchers to identify how the remedies sought and the legal landscape affect the litigants' strategies and any settlement dynamics in different types of cross-border cases, initiated in different Member States.

\title{
CONCLUSION
}

The EU civil justice system is based on a set of PIL instruments which are used to allocate jurisdiction between the different Member States' courts, identify the applicable law in crossborder private disputes, provide administrative cooperation in sensitive fields of cross-border family law (eg child abduction, maintenance and parental responsibility) and provide a system for the recognition and enforcement of final judgments given in one Member State in all other Member States. The authors argue that a harmonised and effective PIL framework may have no alternative (both in terms of what is desirable and of what is possible) in a system of multi-level governance characterised by the diversity of the EU Member States' legal orders, representing different legal traditions and heritages. ${ }^{146}$ However, the nature of

\footnotetext{
${ }^{145}$ P. Bazeley, ‘Analysing Qualitative Data: More Than “Identifying Themes”’ (2009) 2 Malaysian Journal of Qualitative Research 6.

${ }^{146}$ Compare some other views expressed by, R. Nickel, 'From Integration through law to integration through conflict', in D. Augenstein (ed.), Integration through Law' Revisited: The Making of the European Polity
} 
private international law is not and should not be confined to the traditional spheres of jurisdiction, applicable law and the enforceability of foreign judgments if it is to fulfil its role as the glue that holds the European Union together in the private law sphere. A wellfunctioning EU civil justice system will be based on PIL instruments which accommodate a level of diversity in cross-border family law, insist on minimum standards of administrative cooperation in much cross-border family litigation, accommodate a high level of party autonomy in commercial and family matters, respect reverse subsidiarity by interlinking well with global Hague Conference on PIL instruments (eg on child abduction, inter-country adoption, parental responsibility, maintenance, protection of adults, trusts, choice of court and what emerges from the current judgments project) and improve actual enforcement of final decisions.

Evaluating the way the harmonised private international law framework is functioning at the moment in the light of the EU policy-makers' objectives is important for measuring the effectiveness of the EU civil justice framework. This poses the following questions: Do some Member State courts attract more cross-border disputes (or some types of cross-border disputes) than others? Can all EU Member States' courts, within a reasonable time and at a reasonable cost, determine jurisdiction? Can national judges identify swiftly applicable laws when applying the EU PIL instruments? Do national courts and other relevant institutions cooperate effectively, in line with the principle of mutual trust, in cross-border cases? Does the current EU civil justice system provide private parties with an effective remedy as a fundamental right in cross-border cases? ${ }^{147}$ Empirical evidence will be needed, in order to fully explain how the EU civil justice framework, based on harmonised PIL instruments, is functioning at present. Therefore, the authors make a case that empirical evidence is necessary to test the effects of the harmonised PIL instruments on those who need a remedy in cross-border cases.

The diverse legal landscape in the EU, including the various national traditions/regimes, means that the jurisdictional divergences may make a difference for litigants, seeking to obtain an effective remedy. In the EU context, there is a triangular relationship between allocation of jurisdiction before an appropriate Member State court and identification of applicable law, on the one hand, and substantive outcomes in a cross-border

(Ashgate, 2012), p. 121-135; M. Dawson, 'Integration through soft law? New Governance and the Meaning of Legality in the European Union', in D. Augenstein (ed.), Integration through Law' Revisited: The Making of the European Polity (Ashgate, 2012), p. 137-156.

${ }^{147}$ See Recital 38 of the Brussels I Recast Regulation. See more: P. Beaumont and M. Danov, 'The EU Civil Justice Framework and Private Law: "Integration through [Private International] Law”' (2015) 22 Maastricht Journal of European and Comparative Law 706-731. 
dispute, on the other hand. Furthermore the recognition and enforcement of that substantive judgment is a fifth freedom in EU law (free movement of “judgments”) but like the original four freedoms is often not legally absolute and even where it purports to be absolute (eg in Brussels IIa in relation to access rights and the overriding of a non-return order in child abduction cases) in terms of recognition and enforceability may not in fact be actually enforceable in every EU Member State where it needs to be enforced. Hence, qualitative data is required in order to identify the important issues which appear to be affecting and shaping the litigants' strategies, settlement dynamics and enforcement efforts under the current PIL regime. Once these issues have been identified, then it will be possible to address head on the question whether the current PIL framework is effectively pursuing its objectives in crossborder cases. If justice is not administered effectively in cross-border cases, then the empirical data might suggest which issues may need to be addressed by the EU legislator and/or national legislators. 